\title{
The Portrait of The Effectiveness of KKNI-Based Curriculum Implementation as An Internalization Efforts in The 21st Century Skills in Medan State University
}

\author{
Faisal, M. Irawan, S. Susanti, G. N. Eza, S. M. Lova \\ \{* faisalpendas@gmail.com $\}$ \\ Faculty of Education, Medan State University
}

\begin{abstract}
This study aims to describe the effectiveness of KKNI-based curriculum implementation as an effort to internalize 21 st century skills at Medan State University. The focus of the research study is the effectiveness of the implementation of the $6 \mathrm{KKNI}$ tasks, namely: routine assignments, Critical Book Report (CBR), Critical Journal Review (CJR), engineering ideas, projects, and mini research. This research is a descriptive quantitative research, with a sample of 280 students from all state faculties at Medan State University. Data were collected using observation and questionnaire, then analyzed using descriptive statistics. The results showed that the effectiveness of KKNI implementation was obtained on average $3.33(83.25 \%)$ in the Good category. That is, the implementation of the KKNI-based curriculum has gone well at the State University of Medan.
\end{abstract}

Keywords: Curriculum, KKNI, 21st century

\section{Introduction}

Government regulations and provisions regarding the higher education curriculum, mandate that the curriculum must refer to the Indonesian National Qualifications Framework (KKNI) in accordance with Presidential Regulation No. 8 of 2012, namely: the competency qualification framework that can pair, equalize, and integrate education and work and work experience in the framework of providing job recognition in accordance with the work structure in various sectors. The KKNI is an embodiment of the quality and identity of the Indonesian nation in relation to the national education system, the national job training system and the national learning achievement equality assessment system, which Indonesia has to produce quality and productive national human resources.

Following up on Presidential Regulation Number 8 of 2012, Medan State University has formulated an academic service improvement program set out in the 2016-2020 Medan State University Strategic Plan. As a follow-up, each future study program should be able to determine/ compile graduates learning outcomes that have the ability in the field of work, knowledge mastered and have managerial skills. For the formation of courses must pay attention to the profile of graduates, learning outcomes, study materials, and courses as well as the amount of credits. Based on this, each study program at the State University of Medan revitalizes the existing curriculum, which is about the formulation of Graduates' Competencies 
that refer to the KKNI especially at the S1 level (level 6), including: graduate profile, achievement of graduate learning according to the KKNI qualification level, and learning achievement and characteristics of university graduates.

Efforts to obtain graduates in accordance with the description of S1 graduates (level 6) above, Medan State University develops strategies for effective achievement in the implementation of KKNI-based curriculum. The strategy carried out is by giving 6 assignments to students, including: routine assignments, Critical Book Report (CBR), Critical Journal Review (CJR), engineering ideas, projects, and mini research. In its implementation, various guidelines have been prepared for the completion of KKNI tasks at the university level, both in terms of how to complete 6 tasks, and in terms of their assessment. Not only that, the selection of learning models should be based on learning approaches that are oriented to the latest learning concepts [1]-[3].

Based on observations and interviews in the field, namely in several study programs in each faculty, the implementation of the KKNI-based curriculum has not run optimally. In its implementation, there are still many students who do not understand the 6 tasks given and how to solve them. This has an impact on the low quality of the work done by students. Therefore, it is necessary to follow up in the form of in-depth study related to the implementation of the KKNI at Medan State University based on preliminary observations made.

Referring to previous research on the implementation of KKNI in higher education provides the following picture: (1) [4] on "KKNI in Learning Outcomes-Based Curriculum" explains that the KKNI provides a significant impact on improving the quality of graduates in universities, (2) [5] study of "Curriculum Implementation Studies Based on KKNI in the English Education Study Program at the LPTK in Bengkulu City" produced an overview of the mechanism of change and curriculum development carried out so far not standardized based on needs analysis (need analysis), and (3 [6] research on "Development of KKNI and Nationality-Based Education Curriculum as a Sustainable Development Support Program in Education" illustrates that the KKNI-based curriculum is capable of producing graduates who have personal competence, social competence, and intellectual competence with a nationalistic character.

Regarding the research data stated above, it is necessary to conduct a similar study on the implementation of KKNI at Medan State University. In contrast to previous studies, this research study focused more on the effectiveness of KKNI-based curriculum implementation at Medan State University, including the following: (1) student perceptions of the benefits of 6 KKNI tasks, (2) supporting factors and obstacles to KKNI implementation, (3) efforts that can be made to produce implementation of the KKNI at Medan State University.

\section{Methodology}

The type of research used is descriptive quantitative method. Descriptive research (descriptive research) is a research conducted to determine the value of an independent variable, either one variable or more (independent) without making comparisons, or connecting with other variables [7]. Furthermore, it was explained that descriptive research is research that aims to obtain a description of the characteristics of variables (respondent characteristics, messages to be conveyed and respondents' perceptions) [8]. 
The type of research conducted is policy research that has special characteristics in identifying various issues or problems that arise related to policy making and after the data is obtained, researchers conduct policy analysis based on data [2]. Therefore, the application of the KKNI-based curriculum as part of Unimed's policy needs to be reviewed by the readiness of students to follow it.

The purpose of this research is to describe the effectiveness of KKNI-based curriculum implementation at the State University of Medan. In accordance with this goal, what will be obtained from this research is descriptive data in the form of a description of students' perceptions about giving $6 \mathrm{KKNI}$ assignments among them; benefits of $6 \mathrm{KKNI}$ tasks, supporting and inhibiting factors, as well as the efforts made in producing $6 \mathrm{KKNI}$ assignments at Medan State University.

Subjects in this study were 280 first semester students and third semester students of 2017/2018 school year with the following details: 40 people from the Faculty of Education, 40 people from the Faculty of Economics, 40 people from the Faculty of Sports Science, 40 people from the Faculty of Social Sciences, 40 people from the Language and Arts Faculty, 40 people from the Faculty of Engineering, and 40 people from the Faculty of Mathematics and Natural Sciences. The sampling technique is random sampling, based on the assumption of a homogeneous population. Homogeneity of the population is based on the knowledge that all first and third semester students have the same capacity. Data collection techniques, referring to how the data needed in research can be obtained. Sources of data obtained by researchers using observation and questionnaire techniques using data collection instruments in the form of observation sheets and questionnaire sheets were then analyzed using descriptive statistics.

\section{Result and Discussion}

\subsection{Research Results}

3.1.1 Student Perceptions of Benefits 6 Tasks of the KKNI

Many Medan State University students were involved as respondents in the study there were 280 people. The results of the analysis of student perceptions of the benefits of $6 \mathrm{KKNI}$ assignments at Medan State University can be seen in Table 1.

Table 1. Student Perceptions of the Benefits of Implementation of the 6 KKNI Tasks

\begin{tabular}{clccc}
\hline No & \multicolumn{1}{c}{ Task Name } & Average & Percentage (\%) & Qualification \\
\hline 1 & Routine Tasks & 3,4 & 85,0 & $\mathrm{~B}$ \\
2 & Critical Book Report (CBR) & 3,4 & 85,0 & B \\
3 & Critical Journal Review (CJR) & 3,3 & 82,5 & B \\
4 & Idea Engineering & 3,3 & 82,5 & B \\
5 & Mini Research & 3,3 & 82,5 & B \\
6 & Project & 3,3 & 82,5 & B \\
\hline Amount & $\mathbf{2 0 , 0}$ & $\mathbf{8 3 , 2 5}$ \\
\hline Average & $\mathbf{3 , 3 3}$ & Good \\
\hline Qualification & \multicolumn{2}{c}{} \\
\hline
\end{tabular}


Based on Table 1, it can be explained that the average perception of Medan State University students on the benefits of routine tasks given by lecturers is 3.4 in the Good category. Students' perceptions of the benefits of CBR assignments obtained an average of 3.4 in the Good category. Student perceptions of the benefits of CJR tasks, engineering ideas, mini-research, and projects were obtained on the same average, which was 3.3 in the Good category. Thus, the perception of the students of Medan State University on the benefits of the $6 \mathrm{KKNI}$ assignments given by the lecturers obtained an average of 3.33 in the Good category. That is, students have a good perception of the benefits of the 6 KKNI assignments given by lecturers at the State University of Medan.

Simply stated, the description of students' perceptions of the benefits of $6 \mathrm{KKNI}$ assignments at Medan State University can be seen in Figure 2 below.

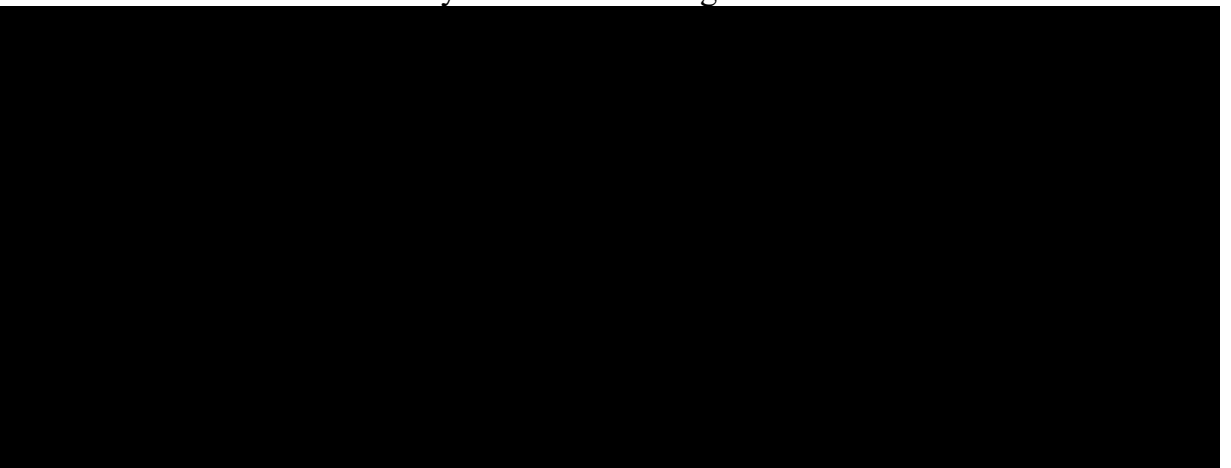

Fig.1. Average Detection Efficiency for Reza (2015) Feature Extraction versus Modified Feature Extraction

\subsubsection{Student Perception of Supporting and Inhibiting Factors for Implementation of the 6 KKNI Tasks}

The results of the analysis of student perceptions of supporting factors and inhibitors of the implementation of 6 KKNI tasks at Medan State University can be seen in Table 2 below:

Table 2. Results of Student Perception Analysis of Supporting and Inhibiting Factors for Implementation of the 6 KKNI Tasks

\begin{tabular}{|c|c|c|c|}
\hline No & Aspects Observed & $\begin{array}{l}\text { Average } \\
\text { Score } \\
1-4\end{array}$ & Qualification \\
\hline \multirow{2}{*}{$\begin{array}{l}1 \\
2\end{array}$} & \multirow{2}{*}{$\begin{array}{l}\text { Availability of learning resources for the implementation of } 6 \text { IQF tasks } \\
\text { Availability of supporting facilities for the implementation of } 6 \text { IQF } \\
\text { tasks }\end{array}$} & 3,4 & B \\
\hline & & 3,2 & B \\
\hline 3 & Availability of guidelines for making $6 \mathrm{IQF}$ assignments & 3,5 & B \\
\hline 4 & Availability of guidelines for evaluating 6 tasks of the IQF & 3,5 & B \\
\hline 5 & Availability of time allocation for $6 \mathrm{KKNI}$ assignments by students & 3,2 & B \\
\hline 6 & Availability of time to receive $6 \mathrm{KKNI}$ assignments by lecturers & 2,5 & $\mathbf{C}$ \\
\hline 7 & $\begin{array}{l}\text { Supervision of the implementation of } 6 \text { IQF tasks by the heads of } \\
\text { departments, faculties, and PT }\end{array}$ & 2,4 & $\mathbf{C}$ \\
\hline \multirow{2}{*}{\multicolumn{2}{|c|}{$\begin{array}{l}\text { Amount } \\
\text { Average }\end{array}$}} & 22,3 & \\
\hline & & 3,2 & \\
\hline \multicolumn{2}{|c|}{ Qualification } & $\begin{array}{c}\text { B } \\
\text { Good }\end{array}$ & \\
\hline
\end{tabular}


Based on the data in Table 2, students' perceptions of the supporting and inhibiting factors of the implementation of KKNI at Medan State University are explained as follows: (1) Availability of learning resources for implementation of $6 \mathrm{KKNI}$ assignments is on average 3.4 with Good category, (2) Availability of supporting facilities The implementation of 6 KKNI assignments was obtained on average 3.2 in the Good category, (3) Availability of guidelines for making $6 \mathrm{KKNI}$ assignments on an average of 3.5 with Good categories, (4) Availability of assessment guidelines 6 KKNI assignments were on average 3.5 with Good category, (5) Availability of time allocation for the making of 6 KKNI assignments by students at an average of 3.2 in the Good category, (6) Availability when examining 6 KKNI assignments by lecturers at an average of 2.5 with the category Sufficient, (7) Supervision of the implementation of $6 \mathrm{KKNI}$ assignments by leaders of departments, faculties, and college is on average 2.4 with the category Enough, (8) the average results of the analysis of supporting factors and inhibitors of implementation 6 the task of the KKNI at the State University of Medan is 3.2 in the Good category. In simple terms, data exposure Table 2 can be seen in Figure 3 below.

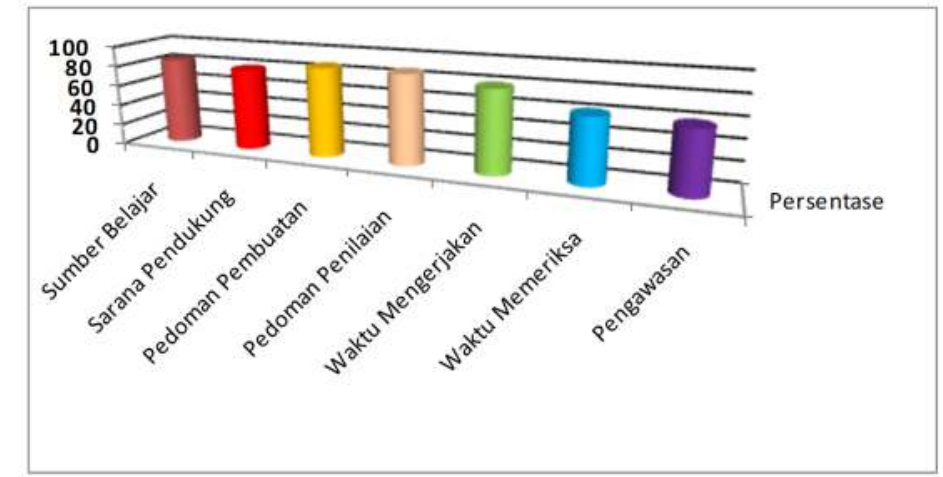

Fig.2. Student Perceptions of Supporting and Inhibiting Factors of KKNI Implementation

Guided by data in Table 2 and Figure 3, students' perceptions of supporting factors and inhibitors of the implementation of 6 KKNI tasks at Medan State University can be analyzed as follows.

\section{(a) Supporting Factors for Implementation of the 6 KKNI Tasks}

Based on the average obtained through the analysis of Table 2 before, the factors that support the implementation of the 6 KKNI tasks include:

1) Availability of learning resources for the implementation of $6 \mathrm{KKNI}$ assignments is good at Medan State University;

2) Availability of supporting facilities for the implementation of $6 \mathrm{KKNI}$ tasks is good at the State University of Medan;

3) Availability of guidelines for the preparation of $6 \mathrm{KKNI}$ assignments has been given by lecturers at the State University of Medan;

4) Availability of assessment guidelines $6 \mathrm{KKNI}$ assignments have been well provided by lecturers; and

5) Availability of time allocation for the making of $6 \mathrm{KKNI}$ assignments by students is still relatively good. 
(b) Inhibiting Factors for the Implementation of the 6 KKNI Tasks

Based on the average obtained through the analysis of Table 2, which is a factor inhibiting the implementation of the $6 \mathrm{KKNI}$ tasks, among others:

1) Availability when checking $6 \mathrm{KKNI}$ assignments by lecturers is still lacking. Based on the results of interviews with several lecturers, the cause of this could occur is the number of teaching hours by each lecturer so that the time to check the assignments is very limited.

2) Supervision of the implementation of 6 KKNI tasks by leaders of departments, faculties, and college is also still relatively low, which is at an average of 2.4 with sufficient categories.

\section{(c) Student Perceptions of Efforts Made to Achieve Success 6 KKNI Tasks}

The description od student perception of the efforts that can be done in order to achive the succesfully implementation of the $6 \mathrm{KKNI}$ tasks at the state University of Medan can be seen in 3 below

Table 3. Results of Student Perception Analysis on Efforts Made to Achieve Successful Implementation of the 6 KKNI Tasks

\begin{tabular}{|c|c|c|c|}
\hline No & Aspects Observed & Average & Qualifica-tion \\
\hline 1 & Provision of guidelines for making $6 \mathrm{KKNI}$ assignments & 3,8 & SB \\
\hline 2 & Provision of assessment guidelines for 6 KKNI tasks & 3,8 & SB \\
\hline 3 & $\begin{array}{l}\text { Ability to explain the implementation of the } 6 \mathrm{KKNI} \text { tasks (types } \\
\text { of bills, forms of assignments, impact if they do not work, and } \\
\text { benefits obtained) }\end{array}$ & 3,3 & B \\
\hline 4 & Provision of alternative learning resources & 3,2 & B \\
\hline 5 & $\begin{array}{l}\text { The strategy of achieving time efficiency in working on } 6 \mathrm{KKNI} \\
\text { assignments by students }\end{array}$ & 3,4 & B \\
\hline 6 & $\begin{array}{l}\text { Strategies for achieving time efficiency in examining } 6 \mathrm{KKNI} \\
\text { tasks by lecturers }\end{array}$ & 3,2 & B \\
\hline 7 & $\begin{array}{l}\text { Improved supervision of the implementation of } 6 \mathrm{KKNI} \text { tasks by } \\
\text { leaders of departments, faculties, and universities }\end{array}$ & 3,4 & B \\
\hline \multicolumn{2}{|r|}{ Amount } & 24,1 & \\
\hline \multicolumn{2}{|c|}{ Average } & 3,4 & \\
\hline \multicolumn{2}{|c|}{ Qualification } & $\begin{array}{c}\text { B } \\
\text { Good }\end{array}$ & \\
\hline
\end{tabular}

Referring to the data in Table 3, the results of the analysis of student perceptions of the efforts that can be done to achieve the successful implementation of KKNI at Medan State University can be seen in Figure 4 below: 


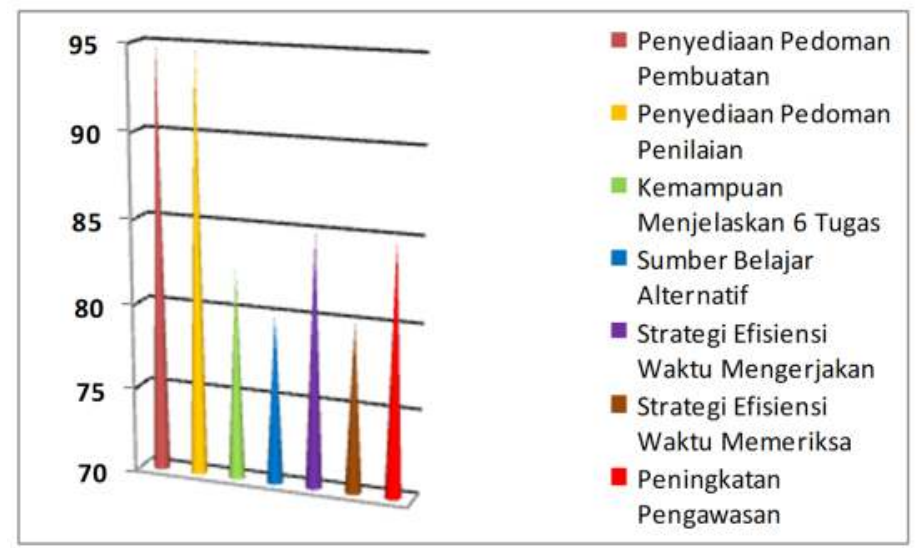

Fig.3. Student Perceptions of the Efforts Performed in Generating 6 KKNI Tasks

Based on the data in Table 3 and Figure 4, the efforts made in producing $6 \mathrm{KKNI}$ assignments at Medan State University are as follows: (1) Provision of guidelines for making 6 KKNI assignments is 3.7 on average with Very Good categories, (2) Provision of assessment guidelines for 6 KKNI tasks is at an average of 3.8 in the Very Good category, (3) Ability to explain the implementation of the $6 \mathrm{KKNI}$ tasks (types of bills, form of tasks, impact if not working, and benefits obtained) by the lecturer on a flat 3.3 with Good category, (4) Provision of alternative learning resources at an average of 3.2 in the Good category, (5) Strategies for achieving time efficiency in working on 6 KKNI tasks by students at an average of 3.4 in the category of Good, (6) Strategy for achieving time efficiency in examining 6 KKNI assignments by lecturers at an average of 3.2 in the Good category, (7) Improved supervision of the implementation of $6 \mathrm{KKNI}$ tasks by leaders of departments, faculties, and PT on average 3.4 in the Good category.

Guided by the above explanation, several efforts have been made to produce the implementation of 6 KKNI tasks at Medan State University, including: maximizing the provision of guidelines for the creation of the $6 \mathrm{KKNI}$ tasks, maximizing the provision of assessment guidelines for $6 \mathrm{KKNI}$ tasks, maximizing explanations related to the $6 \mathrm{KKNI}$ tasks, maximizing resources alternative learning, finding strategies for achieving efficiency efforts made in producing $6 \mathrm{KKNI}$ tasks, referring to the level of effectiveness or success stated by [9] and of completion time and examining $6 \mathrm{KKNI}$ assignments, and increasing supervision of the implementation of $6 \mathrm{KKNI}$ tasks by leaders of majors / study programs, faculties, and universities.

\subsection{Discussion}

Implementation of 6 tasks in order to optimize the curriculum based on KKNI at Medan State University needs to be measured the effectiveness of its achievement. The effectiveness of a public policy in the field of learning is characterized by the following characteristics: (a) successfully deliver students to achieve the instructional objectives that have been set, (b) provide an attractive learning experience, actively engage students so as to support the achievement of instructional goals, (c) having facilities that support the learning process [9]. It was further explained that every minimum policy implementation program in the category of Good (Minister of Education and Culture, No. 23 of 2016). 
Based on the explanation above, every aspect observed was related to the implementation of 6 KKNI assignments at Medan State University which included: (1) student perceptions of the benefits of $6 \mathrm{KKNI}$ tasks, (2) student perceptions of supporting factors and obstacles to the implementation of the 6 KKNI tasks, and (3) student perceptions of the Permendikbud No. 23 of 2016. For more details, can be seen in the following description.

\subsubsection{Student Perceptions of Benefits 6 Tasks of the KKNI}

Guided by the analysis of the results of previous studies, obtained data descriptions as follows: (1) the average student's perception of the benefits of routine assignments given by lecturers was 3.4 in the Good category, (2) student perceptions of CBR task benefits were obtained on average 3,4 in the Good category, (3) students' perceptions of the benefits of CJR tasks, engineering ideas, mini-research, and projects were obtained with the same average, which was 3.3 in the Good category. Thus, students' perceptions of the 6 KKNI assignments given by lecturers obtained an average of 3,33 in the Good category. That is, students have a good perception of the benefits of the 6 KKNI assignments given by lecturers at the State University of Medan.

Referring to the opinion of [9] and Permendikbud No. 23 of 2016 before, student perceptions of the benefits of the $6 \mathrm{KKNI}$ assignments provide a positive picture and provide an overview of the overall improvement of student competence. Thus, if viewed based on student perceptions of the benefits of the 6 KKNI tasks, thoroughly support and have a positive view on the implementation of the 6 KKNI tasks at Medan State University.

\subsubsection{Student Perceptions of Supporting Factors Implementation of the 6 KKNI Tasks}

Based on the average obtained through the analysis of Table 2 before, the factors that support the implementation of the 6 KKNI tasks include:

(1) Availability of learning resources for the implementation of $6 \mathrm{KKNI}$ assignments is good at Medan State University;

(2) Availability of supporting facilities for the implementation of 6 KKNI tasks is good at the State University of Medan;

(3) Availability of guidelines for the preparation of 6 KKNI assignments has been given by lecturers at the State University of Medan;

(4) Availability of assessment guidelines 6 KKNI assignments have been well given by lecturers at the State University of Medan; and

(5) Availability of time allocation for the making of $6 \mathrm{KKNI}$ assignments by students is still relatively good.

\subsubsection{Student Perceptions of the Inhibiting Factors of the Implementation of the 6 KKNI Tasks}

Based on the average obtained through the analysis of research results, which is a factor inhibiting the implementation of 6 KKNI tasks at Medan State University, among others:

(1) Availability when checking 6 KKNI assignments by lecturers is still lacking. Based on the results of interviews with several lecturers, the cause of this could occur is the number of teaching hours by each lecturer so that the time to check the assignments is very limited.

(2) Supervision of the implementation of 6 KKNI tasks by leaders of departments, faculties, and universities is also still relatively low, which is at an average of 2.4 with sufficient categories. 


\subsubsection{Student Perceptions of Efforts Made in Generating Implementation of the 6 Tasks of the KKNI}

The results of the analysis of student perceptions of the efforts made in the implementation of the $6 \mathrm{KKNI}$ assignments at Medan State University are as follows: (1) maximizing the provision of guidelines for making 6 KKNI tasks, (2) maximizing the provision of assessment guidelines for the $6 \mathrm{KKNI}$ tasks, (3) maximizing explanations related to 6 tasks of the KKNI, maximizing alternative learning resources, (4) finding strategies for achieving efficiency in completion time and examining $6 \mathrm{KKNI}$ tasks, and (5) improving supervision of the implementation of the 6 KKNI tasks by leaders of departments, faculties, and universities. Thus, it is hoped that the implementation of the 6 KKNI tasks will achieve success and perfection in the future in accordance with what is aspired..

\section{Conclusion}

Based on the results of the study, obtained some conclusions as follows: (1) Students have a good perception of the implementation of $6 \mathrm{KKNI}$ tasks at the State University of Medan; (2) Supporting factors for the implementation of the 6 KKNI tasks at Medan State University can be seen through several things, including: (a) the availability of learning resources for the implementation of 6 good KKNI tasks; (b) availability of supporting facilities for the implementation of the $6 \mathrm{KKNI}$ tasks that are already good at; (c) availability of guidelines for the preparation of $6 \mathrm{KKNI}$ assignments that have been given by lecturers; (d) availability of assessment guidelines for 6 KKNI assignments that have been given well by lecturers; and (e) the availability of time allocation for the making of $6 \mathrm{KKNI}$ assignments by students is also quite good; and (3) student perceptions of the factors inhibiting the implementation of the 6 KKNI tasks can be seen through several things, including: (a) availability when examining 6 KKNI assignments by lecturers is still lacking. (b) Supervision of the implementation of 6 KKNI assignments by leaders of department / study programs, faculties, and PT is also still relatively low, which is at an average of 2.4 with sufficient categories; and (4) Efforts that can be made in generating the implementation of $6 \mathrm{KKNI}$ assignments at Medan State University can be seen through several things, including: (1) maximizing the provision of guidelines for the preparation of $6 \mathrm{KKNI}$ tasks, (2) maximizing the provision of assessment guidelines for the $6 \mathrm{KKNI}$ tasks, ( 3 ) maximizing explanations related to the 6 tasks of the KKNI, (4) maximizing alternative learning resources, (5) finding strategies for achieving time efficiency and examining $6 \mathrm{KKNI}$ tasks, and (6) increasing supervision of the implementation of the 6 KKNI tasks by the head of the department / study program, faculties, and universities

\section{References}

[1] F. Nasrun, N., Faisal, F., \& Feriyansyah, "Pendampingan Model Pembelajaran Inovatif di Sekolah Dasar Kecamatan Medan Selayang Kota Medan,” J. Pengabdi. Kpd. Masy,, vol. 24, no. 2, pp. 671-676, 2018.

[2] F. Faisal, "Persepsi Mahasiswa PGSD Terhadap Implementasi KKNI di Universitas Negeri Medan," J. Inov. Pendidik. dan Pembelajaran Sekol. Dasar, vol. 2, no. 1, 2018.

[3] F. Farihah, "Learning Media Development Based on 'Meme' as Efforts to Prevent Miscellanee Drug Abuse in Class VI of Elementary School," 2017.

[4] I. Solikhah, "KKNI dalam Kurikulum Berbasis Learning Outcomes," J. Ling., vol. 12, no. 1, 2015. 
[5] A. A. Jono, "Studi Implementasi Kurikulum Berbasis KKNI pada Program Studi Pendidikan Bahasa Inggris di LPTK Se-Kota Bengkulu,” J. Manhaj, vol. 4, no. 1, 2016.

[6] D. Setiawan, "Pengembangan Kurikulum Pendidikan Berbasis KKNI dan Berwawasan Kebangsaan sebagai Program Dukungan Pembangun Berkelanjutan di Bidang Pendidikan," Pap. Present. Semin. Nas. Pendidik. Ilmu-ilmu Sos. Membentuk Karakter Bangsa dalam Rangka Daya Saing Glob. Gd. Clar. Hotel. 29 Oct 2016, 2016.

[7] Sugiyono, Metode Penelitian Pendidikan Pendekatan Kuantitatif, Kualitatif, dan $R \& D$. Bandung: Alfabeta, 2009.

[8] J. P. Spradley, Metode Etnografi (Terjemahan Misbah Zulfa Elizabeth). Yogyakarta: Tiara Wacana, 1997.

[9] H. Firman, Penilaian Hasil Belajar dalam Pengajaran. Bandung: FMIPA UPI, 2010. 